
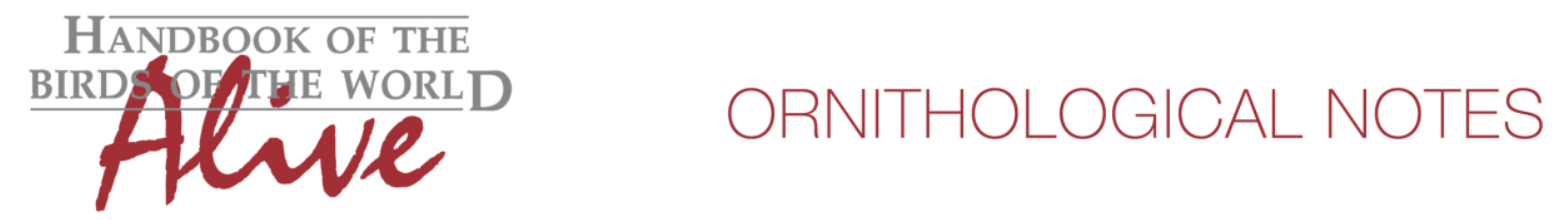

\title{
Notes on the vocalizations of Chestnut-belted Gnateater (Conopophaga aurita)
}

Peter Boesman

In the following we briefly analyze and compare voice of the different races of Chestnutbelted Gnateater (Conopophaga aurita). We also try to quantify the extent of any vocal differences using the criteria proposed by Tobias et al. (2010), as a support for taxonomic review. We have made use of sound recordings available on-line from Xeno Canto (XC) and Macaulay Library (ML).

Song of all races is a long trilled series of notes, and there seem to be two groups which are vocally distinct (Fig. 1).

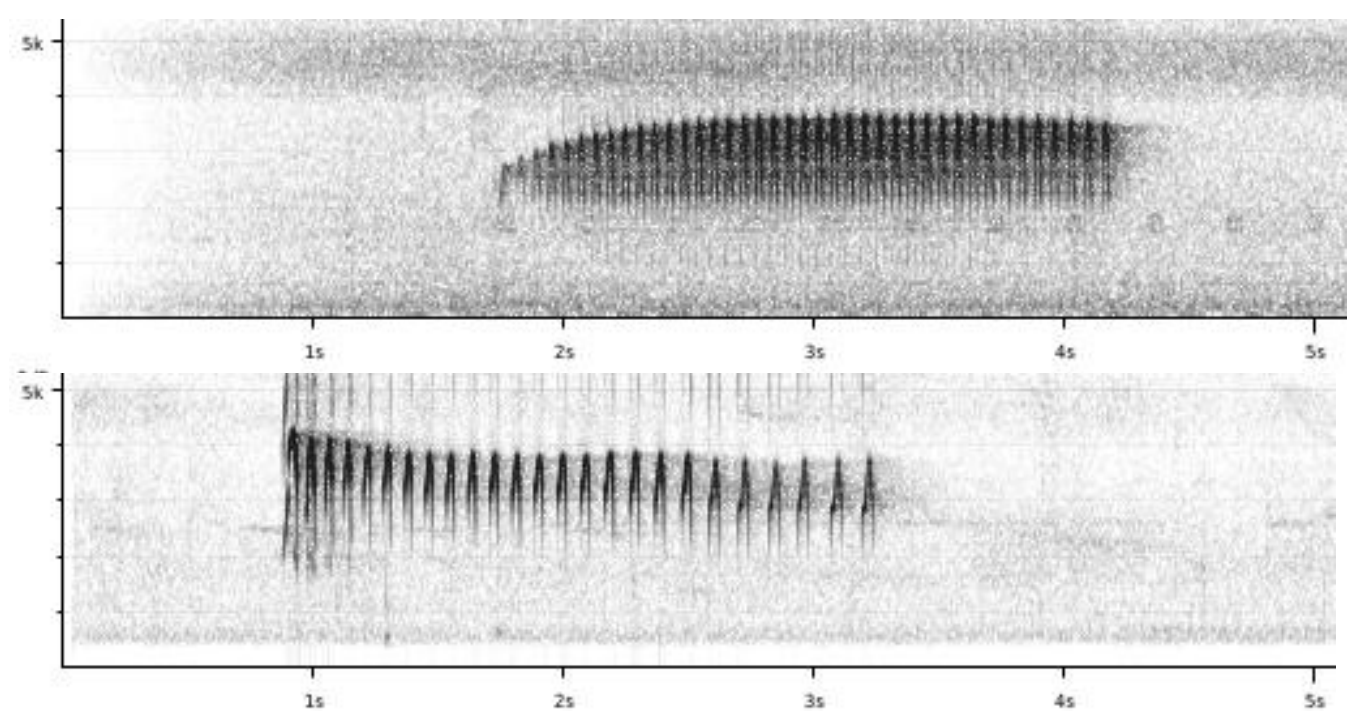

Figure 1: Top to bottom: Typical loudsong from E Ecuador (occidentalis) and SE Amazon (snethlageae)

We have measured some basic sound parameters:

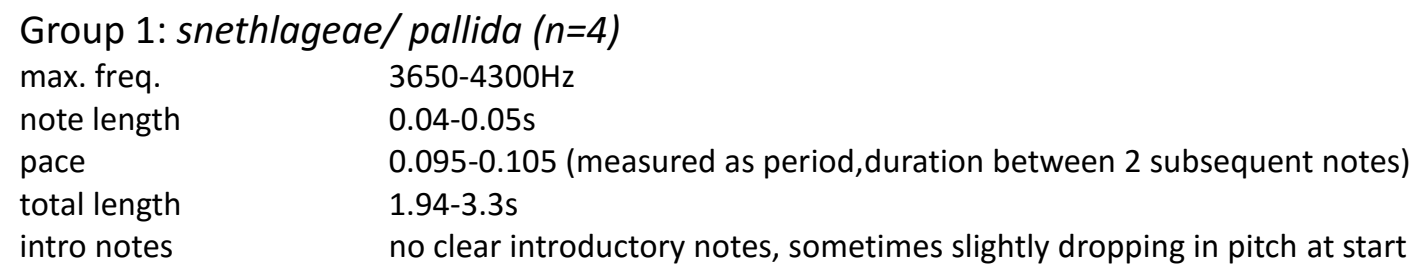

Group 2: other races (australis, occidentalis, aurita, song from Palmari may be inexpectata?) $(n=6)$

max. freq.

note length

pace

total length

intro notes
$3200-4000 \mathrm{~Hz}$

$0.026-0.035 \mathrm{~s}$

0.054-0.06

$1.7-4 \mathrm{~s}$

1-4 introductory notes which rise gradually in pitch at start 

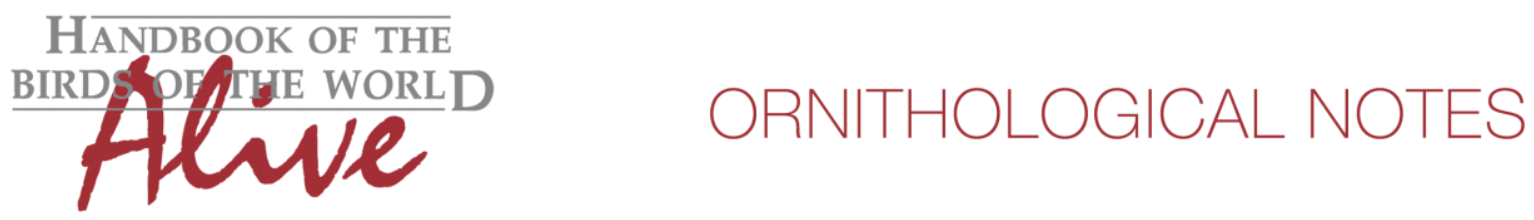

There is a clear difference between snethlageae/ pallida and other races:

Song pace of both groups is remarkably stable, and is much slower in snethlageae/pallida (almost half the speed, score 3), with longer notes (score 2). Furthermore, there are no initial rising notes in the song of snethlageae/pallida.

The latter possibly also slightly higher in frequency, but more samples needed, and score probably only 1.

If we consider pace and note length independent, than vocal difference leads to a quantified total score of 5.

This note was finalized on 13th May 2015, using sound recordings available on-line at that moment. We would like to thank in particular the sound recordists who placed their recordings for this species on XC and ML: Nick Athanas, Peter Boesman, Paul Coopmans, Sidnei Dante, David Geale, Frank Lambert, Dan Lane, Alexander Lees, Gabriel Leite, Curtis Marantz, Jeremy Minns, John V Moore, Otte Ottema, Andrew Spencer and Philip Stouffer.

\section{References}

Tobias, J.A., Seddon, N., Spottiswoode, C.N., Pilgrim, J.D., Fishpool, L.D.C. \& Collar, N.J. (2010). Quantitative criteria for species delimitation. Ibis 152(4): 724-746.

\section{Recommended citation}

Boesman, P. (2016). Notes on the vocalizations of Chestnut-belted Gnateater (Conopophaga aurita). HBW Alive Ornithological Note 65. In: Handbook of the Birds of the World Alive. Lynx Edicions, Barcelona. (retrieved from http://www.hbw.com/node/931949 on 15 May 2016). 